\title{
Non-occupational asbestos related chest diseases in a small Anatolian village
}

\author{
Y I BARIŞ,' M ARTVINLI,' A A ŞAHIN,' N BILIR,' F KALYONCU,' P SEBASTIEN ${ }^{2}$ \\ From the Departments of Chest Diseases, and Public Health,' Hacettepe University School of Medicine, \\ Ankara, Turkey, and Dust Diseases Research Unit, ${ }^{2}$ School of Occupational Health, McGill University, \\ Montreal, $P Q$, Canada
}

Non-occupational endemic pleural asbestosis and mesothelioma have been reported in some Anatolian villages $^{12}$ and tremolite fibres have been found in the lung tissue from some of these patients.

Between 1984 and 1987 we collected four cases with malignant pleural mesothelioma and one each of asbestosis, gastric carcinoma, and lymphoma from a small Central Anatolian village with a population of 425 .

\section{Patients}

All the patients were from Çaparkayi village in the Şabanözü area of Çankiri district. There is no asbestos mine, mill, or factory in the village. The main sources of income of the inhabitants are from agriculture and live stock breeding. Their houses are made from mudbrick and rocks, the walls of which are plastered with a white stucco.

CASE 1

A 26 year old woman was admitted to hospital with right sided chest pain of ten months duration. She was a housewife and a non-smoker. Positive findings on clinical examination were dropped shoulder and frozen chest on the right side with stony dullness and diminished breath sounds. Chest $x$ ray examination reported a pleural effusion on the right side without mediastinal shift. Pleural punch biopsy was carried out and a malignant pleural mesothelioma was diagnosed.

\section{CASE 2}

A 30 year old woman was referred to hospital with chronic right sided pleural effusion. She was born and raised in Çaparkayi and went to live in Ankara when she was 20 . She was a non-smoker and a housewife. Repeated pleural punch biopsies were non-diagnostic and so a limited thoracotomy was undertaken and malignant pleural mesothelioma was diagnosed his-

Accepted 2 November 1987 tologically. Chest $x$ ray films of her father and mother were reviewed and showed calcified pleural plaques and fibrosing pleuritis compatible with asbestos exposure.

\section{CASE 3}

A 33 year old woman was admitted with chronic right sided exudative pleural effusion. She was born and lived in Çaparkayi until at 19 she left for Ankara. She was a housewife and a non-smoker. Chest $x$ ray examination showed a pleural effusion with irregular nodulation. Computed tomography of the thorax showed pleural effusion, irrregular nodular pleural thickening, and irregular changes in the horizontal fissure. Malignant pleural mesothelioma was diagnosed by pleural punch biopsy. Her father's chest $x$ ray film showed linear calcification above the right diaphragm compatible with asbestos exposure.

\section{CASE 4}

A 40 year old woman was admitted to hospital with left sided chest pain and shortness of breath of five months duration. She was born and lived in Çaparkayi until at 21 she left for Ankara. She was a housewife and a non-smoker. Clinical and radiological studies showed a left sided chronic pleural effusion in the absence of any infectious or collagen diseases. Malignant pleural mesothelioma was diagnosed after limited thoracotomy and she died six months after diagnosis.

\section{CASE 5}

A 58 year old woman was admitted to the hospital because of shortness of breath. She was born and lived in Çaparkayi until she was 45 . She was a housewife and a non-smoker. She was dyspnoeic and had finger clubbing. Breath sounds were diminished and diffuse late inspiratory crackles were heard over the middle and lower zones. The chest $x$ ray film showed diffuse linear fibrosis mainly in the lower lung. Microbiological and cytological examination of the sputum were not helpful. The results of pulmonary 
function tests and arterial blood gas analysis were compatible with a restrictive lung disease. Fibreoptic bronchoscopic examination showed a normal tracheobronchial system and multiple transbronchoscopic biopsy specimens were taken from the right lower lobe. Histological examination of the specimens showed mononuclear inflammatory cells, mild thickening of the alveolar walls, and interstitial fibrosis. Mineralogical examination of one biopsy specimen showed many fibres that were identified by a combination of detailed morphological observation, $x$ ray microanalysis, and electron diffraction as tremolite. She was diagnosed as having asbestosis and a clinical follow up was suggested.

CASE 6

A 56 year old man was admitted to hospital with epigastric pain. He was born and lived all his life in Çaparkayi. He was a farmer and a heavy smoker. Gastric carcinoma was diagnosed after a barium meal and confirmed by laparotomy. He died three months later.

\section{CASE 7}

A 50 year old woman was admitted to hospital because of a neck swelling of four months duration. She was born and lived all her life in Çaparkayi. She was a housewife and a non-smoker. Physical examination showed multiple, discrete, rubbery lymph nodes in both anterior and posterior cervical chains. A lymph node biopsy was performed and mixed cellular type Hodgkin's disease was diagnosed.

\section{Discussion}

All patients had lived in Çaparkayi and were never occupationally exposed to asbestos, although the patient with asbestosis had many fibres in her lung tissue. Tremolite has been found in the stucco from certain villages in Central Anatolia ${ }^{12}$ and these patients may have inhaled tremolite asbestos from the walls of houses plastered with white stucco. Stanton et $a l^{3}$ and Wagner et $a l^{4}$ have shown that tremolite is a powerful mesothelial carcinogen in animals and there are also studies that suggest it may cause malignant pleural mesothelioma. ${ }^{56}$
Mesothelioma in asbestos workers is commonly diagnosed between the ages of 50 and 70 , and the interval of the first exposure to asbestos and emergence of the tumour is usually 20 to 40 years. ${ }^{78}$ The young age of our patients may easily be explained by childhod exposure to asbestos.

One of the patients had gastric carcinoma. Although this could be coincidental, there are studies that point to a more than expected proportion of digestive tract cancers in asbestos workers. ${ }^{910}$

Case 7 has mixed cellular type Hodgkin's disease and this may also be related to asbestos. Efremidis et al reported two lymphocytic neoplasms, chronic lymphocytic leukaemia, and lymphoma in patients who had non-occupational exposure to asbestos. ${ }^{11}$

The collection of four cases of malignant pleural mesothelioma in a village with a population of 425 is unusual and the detection of tremolite fibres in the lung tissue of one patient with asbestosis suggests that tremolite was the cause.

\section{References}

1 Bariş YI, Artvinli M, Sahin AA. Environmental mesothelioma in Turkey. Ann NY Acad Sci 1979;330;423-32.

2 Yazicioğlu S, Ilcayto R, Balci K, et al. Pleural calcification, pleural mesotheliomas, and bronchial cancers caused by tremolite dust. Thorax 1980;35:564-9.

3 Stanton MF, Lazard M, Tegeris A, et al. Relation of particle dimension to carcinogenicity in amphibole asbestoses and other fibrous minerals. J Natl Cancer Inst 1981;67:965-75.

4 Wagner JC, Chamberlain M, Brown RC, et al. Biological effects of tremolite. Br J Cancer 1982;45:352-60.

5 Magee F, Wright JL, Chan N, et al. Malignant mesothelioma caused by childhood exposure to long-fiber low ration tremolite. Am J Ind Med 1986;9:529-33.

6 McConnochie K, Simonato L, Mavrides P, et al. Mesothelioma in Cyprus: the role of tremolite. Thorax 1987;42:342-7.

7 Elmes PC, Simpson MJC. The clinical aspects of mesothelioma. $Q$ J Med 1976;179:427-9.

8 Hillerdal G. Malignant mesothelioma 1982; review of 4710 published cases. Br J Dis Chest 1983;77:321-43.

9 Selikoff IJ, Churg J, Hammond EC. Asbestos exposure and neoplasia.JAMA 1964;188:22-6.

10 Newhouse ML, Berry G, Wagner JC. Mortality of factory workers in East London, 1933-80. Br J Ind Med 1985;42:4-11.

11 Efremidis AP, Waxman JS, Chahinian AP. Association of lymphocytic neoplasia and mesothelioma. Cancer 1985;55:1056-9. 